\title{
GLOBALISATION, HUMAN RIGHTS AND ISLAM: COMPETING NARRATIVES AND DISCURSIVE PRACTICES IN THE MUSLIM WORLD
}

\author{
Asif Mohiuddin*
}

\begin{abstract}
Globalisation - the growing interpenetration of ideas, states, and markets across borders - has not only fostered the very blurring of distances but also growing avenues of appeal for citizens suppressed by their own states. There is no doubt that, in contemporary times, international norms and institutions for the protection of human rights are more developed than at any previous point in history. However, assaults on basic human rights continue, and the emergence of a global human rights regime may also be engendering new sources of human rights abuse. This paper examines how these developments have transformed the complex and mutable relationship between human rights and Islam and how this relationship is readjusting in response to the changing global situation. Focusing on the dramatic expansion of human rights discourse in the Muslim world, the paper argues that, for critics of Islam, the position on the incompatibility of Islam and human rights, which assumes two settled entities in an unstable relationship, is becoming hard to sustain - as is the position on the Western origin of human rights. The main implication of this study is that human rights principles can be a binding international norm in a globalised world and that many normative conventions can play a pioneering role in promoting these rights and contribute to the emergence of a multicultural society.
\end{abstract}

Keywords: Globalisation; Ethics; Human Rights; Islamic Law; Maqasid alShari 'ah; Middle East.

\section{Introduction}

Across a wide array of disciplines and perspectives, the terms "globalisation" and "human rights" encapsulate two of the most spectacular areas of concern that have brought on new forms of domination and new ways of alleviating social suffering through interventions in the realm of social and economic freedom. One of the main issues in the study of the globalisation of human rights is the way universal ideas of human rights intersect with local or regional ideas of rights, which are often seen to be contradicting and even hostile to the rights specified in particular cultural and religious traditions. ${ }^{1}$ While not specifically couched 
in the language of relativism, many anthropologists argue "that there could be no such thing as rights outside of particular cultures and that Western ideas of human rights represented a form of cultural imperialism." ${ }^{22}$ In this context, while criticising the destructive nature of human rights language, representatives of world religions such as Islam found the fundamental character of the intersection of a universalising human rights culture and local culture contrary to the norms and values in various locales. For decades, however, Muslim scholars have debated whether Islam contradicts modern human rights norms and conventions, or whether Muslim traditionalists "feel compelled to use the language of human rights to justify their political ambitions." ${ }^{33}$ Having generated a rich body of academic literature, the debate regarding the compatibility between Islam and human rights has often focused on a literalist reading of the authoritative texts emphasising the gaps between the parameters of tolerance and acceptability in the textual sources (i.e. the Qur'an and Sunnah) on the one hand, and internationallysanctioned standards concerning the status of women, religious freedom, matters of legal judgment, on the other. It is perhaps ironic that the literalist reading of the texts have made some traditionalist Muslim leaders oppose the idea of a human rights regime. They believe that the Western powers have set the agenda for human rights, which is seen as nothing more than a pretext for a neo-colonial attempt at regaining domination over the Muslim world. ${ }^{4}$ This has led some Muslim jurists to reject the 1948 declaration as un-Islamic, since, according to them, the principles enshrined in the Universal Declaration of Human Rights contravene the authoritative corpus of the Islamic tradition. ${ }^{5}$

Resting on a belief in the immutability of the Islamic tradition, the above position accentuates the timeless and eternal nature of Islamic injunctions, which cannot be continuously modified to suit changing times. Indeed, some authors have used the same point regarding the temporal alteration of Islamic law to criticise ruling classes. For instance, Sayyid Qutb, the famous Egyptian Muslim reformist, repudiated the Egyptian state for allowing society to follow the path of secular reformation. ${ }^{6}$ Focusing on this theme, Saeed argues that there is nothing certain and undeniable about the literalist approach to the text. The Qur'anic verses that were revealed over more than two decades during the Prophetic era often refer to specific cases involving a certain degree of interpretation and choice. In recognising the uncertainty of the literalist readings of the texts, Saeed advocates recognition of human agency, which not only gives meaning to the texts, but also offers innovative opportunities for exploring the relevance of Islam to contemporary situations and challenges faced by Muslims today. ${ }^{7}$ The above recommendation holds significant promise on the compatibility between human rights and Islam since many Muslim scholars have moved away from ideological inflexibility, emphasising instead the unity between God and humankind and the 
core values embedded in the textual corpus of Islam. In this perspective, religious freedom, freedom to pursue a personal path to divinity, freedom of thought and expression, including freedom from government control and suppression, and freedom of women are seen to be in consonance with the Islamic faith. As Dalacora notes, Muslim scholars/jurists defend human rights not only "because they are concerned with protecting their own rights, as individuals and as an organisation. They also defend rights because they are intent on presenting a picture of a moderate and respectable movement." " This approach, which places the individual, particularly the Muslim believer, in the centre by emphasising the intrinsic values of individual piety and freedom to pursue social and economic development, may therefore be called the humanist approach. In what follows, this paper will explore the impact of globalisation on human rights by considering how the globalisation of rights as a process involves the movement of universal ideas of human rights into new cultural locales and spaces. While shedding light on the local conception of rights, the paper treats in a theoretical and practical vein the relationship of human rights to Islam. It argues that this relationship adds innovative positive dimensions to the human rights debate, since, unlike international conventions, it connects them to a divine source, thereby adding a new ethical/normative motivation for complying with them. Finally, the paper rejects monolithic conceptualisations of both Islam and human rights and looks at the situation of human rights in the Muslim world in the context of shifting political, social and economic dynamics.

\section{Globalisation and the Local Conception of Human Rights: Thinking Beyond the Global/Local Divide}

Since globalisation has generated a vast body of literature, it comes somewhat of a surprise to notice that relatively few works have focused on the relationship between globalisation and human rights. ${ }^{9}$ Perhaps the lack of studies on globalisation and human rights might be explained by the vagueness of many works, which fail to offer refining concepts and evidence to assess the meaning and implications of economic, political, cultural, technological and transnational dimensions of globalisation. ${ }^{10}$ One such gap in the literature concerns how human rights-related institutions and policies are globally enforced, and how human rights are affected by conflict, politics, and exchanges in technology, culture, and society. It is very important to explore the relevance of globalisation for human rights in countries, particularly in the Muslim World, where limited political freedoms, socioeconomic inequality and state repression pose grave challenges to human rights. However, if globalisation is addressed effectively, "it potentially 
could lift millions out of poverty while granting them greater political freedoms; if, on the other hand, it forms part of a hegemonic project that merely advances Western or other narrow economic and political interests, then vast numbers of the world's citizens stand to see what limited rights they may currently hold eroded yet further." 11

It has been argued that globalisation accelerates the process of cultural diffusion, and one of the central ideas that has been affected as a result of this diffusion is the idea of human rights. This idea serves as a template for actors who wish to assist other marginalised groups and individuals in their quest for freedom and development. According to Engle, the implementation of human rights has been conditioned by the adoption of the Universal Declaration of Human Rights (UDHR) in 1948, which provoked an intense critical response from scholars, who believed that there could be no universal conception of human rights that would be valid across the world's wide variety of cultures. ${ }^{12}$ The UDHR was subjected to a process of intense debate and dialogue among representatives of different groups arguing for civil political rights (representatives of Western democracies), and social and economic rights (representatives of communist regimes). ${ }^{13}$ Nevertheless, while there was no consensus on what constituted 'rights' among the drafters, such differences were overlooked because the latter were fully aware that the declaration would not challenge the authority of, say, the obdurate power of the state in autocratic societies. So, even though the UDHR emerged as a normative template for human rights and was seen to be valid across the globe, it lacked the power of authentic, collective agreement and consensus. Nevertheless, this declaration remains a key platform by which the ideas of human rights can advance and possibly be accomplished on a more global scale.

As noted by Cowan et al., scholars have focused on a dialogical project in which advocates of universal human rights attempt to assist vulnerable individuals in escaping the universalism-relativism dichotomy. ${ }^{14}$ In the contemporary phase of globalisation, this dialogical practice proceeds with an understanding of one's cultural ideals and negotiates and persuades members of a culture regarding the authenticity and sacred meaning of certain practices to produce new hybrid practices that can protect the vulnerable. It also recognises, as Dembour has argued, that the validity of certain cultural practices is based on pure relativism, which might lead to indifference and acquiescence, since any intervention making human rights a universalising project would be considered an intrusion into other peoples' cultures. ${ }^{15}$

The dialogical practice represents a new facet of the contemporary globalisation of human rights, with activists in indigenous movements seeking assistance from human rights experts across the globe in framing their causes in the language of human rights. ${ }^{16}$ However, the dialogical approach does not 
address the problem of relativism, nor does it respond to the charge made against human rights advocates in regard to cultural imperialism-despite accepting the validity of other cultural practices.

\section{A Maqasid-based Approach to Human Rights}

Islam aims to establish a code of ethics, or a legal framework, that balances the protection of the rights of the individual with the rights of the society collectively. It achieves that by outlining the essential requirements that would ensure that the rights of the individual are fulfilled without damaging the public good (maslahah) - or, in other words, preserving "the general availability of all the basic human requirements, balanced with public welfare." ${ }^{17}$ The primary objective of the shariah is to secure benefits for the people and safeguard their interests in this world and the hereafter. Characterising public interest as the only principal objective of the shariah, al-Shatibi placed a great deal of emphasis on the objectives (maqasid) of the shariah, pointing out that God revealed the shariah for the benefit of mankind, which can be seen as a unifying factor in all detailed rulings of the shariah. For Kamali, while the objectives of the shariah are "rooted in the textual injunctions of the Qur'an and the Sunnah," their focus is on "the general philosophy and objectives of these injunctions often beyond the particularities of the text." ${ }^{18}$ This makes shariah more accessible, since it avoids atomism, literalism and the intricacies associated with the usul methodology.

Muslim scholars have classified the objectives of the shariah into three categories, listed in descending order of importance as the essentials (daruriyyat), the needs (hajiyyat), and the complementaries (tahsiniyyat). These objectives are usually enumerated into five elements: faith, life, intellect, lineage and property. The essential interests across the five objectives are considered as absolute minimums for the material and spiritual welfare of individuals. These constitute the central theme of the shariah, with all its laws aiming to preserve these benefits. The needs not only seek to promote the essentials, albeit in a secondary way, but also to remove sternness and hardship in cases where such severity and harshness do not pose a threat to the very existence of normal order. The third category of objectives seeks to enhance, refine and perfect the customs and conduct of the people, at all levels, extending beyond the institutional application of almost all aspects of the shariah. ${ }^{19}$

Since the Qur'an has conferred many rights on human beings in the realms of the social, ethical, political, cultural and other fields, it can be argued that the main objective of shariah is to protect the interests and rights of man. These rights cannot be altered, repealed or invalidated under any circumstances, except with 
regards to what is specified in the divine revelation..$^{20}$ Therefore, the maqasidbased approach is a formulation of ideas, concepts and a philosophy of human rights that enhances the aims of the shariah, as opposed to postmodern liberalism and social anarchy, which promote a monolithic view of human rights devoid of any moral significance. While incorporating human rights into the framework of social justice, the maqasidi approach, in the context of preservation of faith, focuses on two types of rights, namely freedom of worship and freedom of belief. These rights are realised when the religious beliefs of a person are not considered as an offence, leading to the preservation of individual and social rights. Similarly, in regard to the protection of life, the basic rights include "right to life, right to security, right to necessities and right to freedom from fear." ${ }^{\text {"21 }}$ Life is an indispensable aspect of development and, as such, covers all dimensions of sustenance, including the rights of those "who are designated as vicegerents of God for ensuring justice and stable governance." 22

Regarding the preservation of mind, some of the basic rights, such as freedom of thought, right to freedom of expression, and capability rights, are discerned to be extremely important for achieving freedom and liberating the human soul from oppression. Accordingly, some jurists situate these rights in the context of daruriyyat, which is in line with the universal right to freedom of conscience and belief. ${ }^{23}$ For Chapra, "no civilization can survive if its future generations are spiritually, physically, and mentally of a lower quality than the previous ones and are, therefore, unable to respond successfully to the challenges that they face. There must, therefore, be continuous improvement in the quality of the future generation...."24

Announced in 1981, the Islamic Declaration of Human Rights includes "the entire list of basic rights that were mentioned in the Universal Declaration of Human Rights (UDHR), such as rights to life, freedom, equality, justice, fair trial, protection against torture, asylum, freedom of belief and speech, free association, education, and freedom of mobility." ${ }^{25}$ However, some members of the United Nations High Commission for Human Rights (UNHCHR) were apprehensive of the changes brought via the Islamic declaration, because they think that such transformations undermine the international human rights instruments which are based on inter-cultural consensus. For others, the declaration "adds new positive dimensions to human rights, since, unlike international instruments, it attributes them to a divine source thereby adding a new moral motivation for complying with them. ${ }^{26}$ Supporting the latter view, while addressing the concerns of the former, a maqasid-based approach to the issue of human rights rectifies the partial picture of Muslim opposition to universal human rights, and plays a fundamental role in juridical reasoning, especially in the evolution of purposes of Islamic law, giving human rights and human development targets a firm base in the Muslim world. 


\section{Competing Tendencies: Debating Human Rights in the Muslim World}

Since the beginning of the twentieth century, the differences between classical and contemporary interpretations of Islamic law have deepened, with some scholars emphasising a clear distinction between the universality of human rights and Islamic ethical constructs. Conceding to several claims made by the supporters of international human rights, Muslim reformists agree that there is a global consensus, in both theoretical and practical terms, regarding the fundamental standards of human dignity. The debate regarding the right to development has assumed a renewed significance in the wake of the ICT revolution, which has resulted in changing attitudes about a broad implementation of human rights and fundamental freedoms. ${ }^{27}$ The realisation of the right to development hinges on necessary organisational changes. However, the willingness of developed countries in the Global North to support such transformations is doubtful. At the same time, the recognition of such a right, when it takes the form of ethnodevelopment, in the wake of an ethnonationalist revival among minority communities in the Middle East, will have profound implications for some states in the region..$^{28}$

Middle Eastern states are organised around a nation-state system. As Beeley has noted, "Islam can replace nationalism as a basis for legitimacy and allegiance if it is permitted to do so by individuals, groups and states, but it shows no sign of replacing the state." ${ }^{29}$ While Muslims differ over the question of adjusting to the state of global politics, they also contest the authoritative definitions of culture, Western values, institutions, and practices, which reflect the current struggle in the Muslim world in which power interests assert competing claims to cultural symbols that are highly valued in the region. ${ }^{30}$ Some Muslim scholars oppose the influence of Western ideas, practices and values. For them, Islam is an immutable religion that transcends time and space. Their purported objectives include the establishment of an Islamic state based on shariah and "the execution of a constitution that is compatible with Islam." ${ }^{31}$ In regard to human rights, they have objected to at least two Articles of UDHR: Article 16 and 18. According to Article 16-1: Men and women of full age, without any limitation due to race, nationality and religion, have the right to marry and to found a family. They are entitled to equal rights as to marriage, during marriage and its dissolution..$^{32}$ Islamists, however, challenge the status of women and question gender roles, marriage rights and obligations, while also advocating a strong version of cultural relativism in which political and socio-economic equality of the sexes is unnatural. Islamists also question the universality of Article 18: 
Everyone has a freedom of thought, consciousness and religion; this right includes freedom to change his (or her) religion or belief, and freedom, either alone or in community with others and in public or private, to manifest his religion or belief in teaching, practice, worship and observance. ${ }^{33}$

According to some jurists, leaving one's religion clearly presents a danger of falling away from Islamic teachings, and thus proselytisation and apostasy should be forbidden by law. Such a monolithic interpretation of Islamic law has invited controversy and debate from leading cadres of Muslim scholars, who seek a balance between traditional, modern and Islamic principles. Thus, for other Muslim jurists, nothing in the law relating to apostasy derives from the letter of the Qur'an as there is no mention therein of any penalty for those who renounce Islam. Nor do any Qur'anic verses refer, explicitly or implicitly, to use force if apostates refuse to return to Islam. ${ }^{34}$ Accordingly, a number of prominent classical Muslim jurists, such as Ibrahim al-Nakhai (d.714), Sufyan al-Thawri (d.778), and Sarakhsi (d.1096) argued that although apostasy is a great offence, an apostate should be asked to repent indefinitely but never condemned to death. ${ }^{35}$ This view was also held by Mahmud Shaltut (the former Rector of al-Azhar), who argued that the prescription of the death penalty for apostasy was aimed at prevention of aggression against the Muslim state. As noted by Ramadan, since there can be no compulsion or coercion in matters of faith because free choice and willing submission "are foundational to the first pillar (declaration of faith) and essential to the very definition of Islam," it should be stated that one who leaves his/her religion should be free to do so and his/her choice must be respected. ${ }^{36}$ Similarly Brown argues that the Qur'anic proclamations regarding compulsion in religion ("There is no compulsion in religion. The right path has been distinguished from error") and freedom of religion ("whoever wants, let him believe, and whoever wants, let him disbelieve") are absolute and universal statements by virtue of which the Qur'an grants religious freedom to Muslims. ${ }^{37}$ In his exhaustive investigation of penal laws in Islam, Khalid El-Fadl emphasises that belief and conviction cannot be coerced or contradicted by isolated traditions attributed to the Prophet, making it clear that there is no punishment prescribed for apostasy. ${ }^{38}$

These scholars advocate a paradigm shift in Islamic thinking, promoting a model of vibrant civil society and a pluralistic political rule by calling for religion to adapt its norms and ethical principles to those of universal human rights conventions. While calling for the renegotiation of gender relations, they argue for the incorporation of new social norms into the framework of gender equality in the midst of the new technological revolution and the international division of 
labour in the Muslim world. In short, although some Muslim jurists warn about the implications of globalisation in the realm of economics and politics, they see it as a liberalising process with palpable consequences to human rights.

\section{Human Rights and the Expanding Global Ethical Space}

With the emergence of revolutionary modern technology and communications, new global awareness has given credence to the universal standards of human rights, which represent, in the most basic sense, the ethical dimensions of an evolving global culture. ${ }^{39}$ In this context, it is important to understand how proper human rights standards are defined by both the Muslim diaspora and those living in Muslim-majority contexts who believe that the considerations of local cultures must be adapted to the concerns of an evolving global civil society. Since the globalisation process has transformed traditional cultures, Muslims have often responded to these changes with anger and frustration. For example, in the cases of the Rushdie Affair and the Gulf War, Muslim responses were based on resentment and passion rather than reflection and pragmatism. This has resulted in, as Ahmad and Hastings have argued, "a more pronounced polarisation in the Muslim world, one which creates a disjunction between radical Islam and the West." ${ }^{40}$ Some human rights practitioners have argued that since a global communication space is evolving with definitive normative implications, the irreversibility of the space has given a political orientation to the application of global human rights standards, which in terms of the inclusion or exclusion of values in a global culture gives preference to politics rather than the underlying philosophy behind rights. ${ }^{41}$ Regarding the role of Islam in this emerging culture, particularly against the backdrop of growing economic, political and social transformations, it is important to note that it has generated distinctly Islamic responses to the growing forces of modernisation and globalisation. The powerful movements spawned by globalisation have forced Islamists to search for pragmatism in the realm of human rights in order to create an effective balance between universal civility and cultural integrity.

Against this backdrop, liberal Muslim reformers admit that it is imperative to have a normative consensus across cultural and religious boundaries to resolve tensions between traditional shariah norms and the requirements of human rights, to seek out ways to genuinely mediate between competing normative requirements. Some scholars focus on the original significance of the shariah based on certain ethical and religious principles. The conjoining of these principles with medieval reasoning recaptures the normative requirements of Islam that have been overshadowed by a legal body of detailed regulations. This 
body of particulars took a rigid and formalistic turn alien to the original substance of the shariah, leading to the situating of incidental worldly matters in the context of essential and immortal provisions of religion. ${ }^{42}$

While advocating an emancipated understanding of the shariah, Muslim reformers demand the recovery of ijtihad in order to achieve justice and address modern needs ${ }^{43}$ For An-Na'im, the task of the Muslim community is to formulate normative criteria in light of theological principles, not only to facilitate reform, both in the fields of law and theology, but also to evolve a new awareness of the human character of the Qur'anic revelation. ${ }^{44}$ It is no coincidence, in that context, that Muslim reformers place a great deal of emphasis on human dignity and focus on the vicegerency of man (Qur'an 2:30). They cite the verse of the Qur'an that emphasises honouring the children of Adam and point out that, according to Qur'anic verse 33:72, God has bestowed a special trust upon His creation, elevating the human being above all cosmic powers. In order to contest traditional hierarchies, Hassan refers to the main doctrine of Islam, the oneness of God (tawhid), and rejects all human pretensions of guardianship, since the ultimate judgment of a person's vocation and destiny lies exclusively with God. ${ }^{45}$ The monotheistic creed thus yields emancipatory consequences, because it questions all claims of absolute obedience by which a human being takes a quasi-divine role, which would come close to polytheism, which is strictly forbidden in Islam.

In his writings, the Tunisian scholar Muhammad Talbi focuses on the same argument in order to demand religious freedom beyond the confines of limited tolerance. For him, a Muslim's submission to God should lead to the recognition of an individual's freedom of conscience. With regard to the traditional forms of corporal punishment, Talbi distinguishes between the essential Qur'anic principles and historical circumstances, with the former remaining valid, even though the modes of implementation can change in accordance with new situations and possibilities. From the above discussion, it seems that the traditional impediments to the endorsement of human rights can be critically overturned, because for many Muslim scholars there is no contradiction between the principles and emancipatory claims of universal human rights as embodied in the existing global standards. The idea of human dignity requires a political commitment to human rights, and in a world where crimes perpetrated against others are blatantly ignored, it is the responsibility of Muslim theologians to repudiate all forms of discrimination as crimes explicitly condemned by the Qur'an. 


\section{Current Realities and Human Rights Alternatives}

Behind common images of the Muslim world, which coalesce around issues of extraordinary violence, as currently epitomised by the omnipresent images of al-Qa'ida, genocides in Iraq and the unending Palestinian-Israeli conflict, lies a dreary authoritarian landscape. Virtually all independent human rights monitors have listed the Muslim world as the worst violator of human rights. During the last several decades, notwithstanding democratising experiments in Bahrain and Yemen, "the average level of freedom has declined within the Middle East," with regimes showing no commitment to establishing rights to non-discrimination, health, education and political liberties. ${ }^{46}$ The region's catalogue of violations ranges from torture and extra-judicial disappearances and killings, to political, economic, and social discrimination against non-Arab minorities.

While linking human rights to equitable economic development, scholars and practitioners have claimed that the failure to implement human rights in the Middle East has led to a process of economic underdevelopment characterised by the exclusion of social, economic, political as well as civil rights. When these rights are incorporated into a state's constitutional framework, they can be conceptualised in a manner that acknowledges the context for rights violations and the range of issues that would lead to an increased awareness of the activities of government in violating human rights and civil liberties. While the Middle East has a comparative advantage in terms of human development relative to Asia and Latin America, the regimes in the region have abused the centralisation of economic resources as a tool for gaining power- doling out economic favours to gain political support undermines civil society cohesion. Overall, economic levels have become stagnant, with minimal efforts being made to empower the political and economic status of the population and establish sustained economic development within the region. ${ }^{47}$

With the evolution of the Middle East's post-revolutionary republics into family-run empires, regimes have focused on the overdevelopment of external and internal security apparatuses, resulting in increased military spending. Flowing out of a lack of political, economic and cultural freedoms and rights, the Middle East's autocratic regimes have flourished in a climate in which the systematic violation of human rights are bred by the ill-effects of colonial structures of power that have enabled these regimes to acquire the support of superpower patrons, regional and international organisations, domestic institutions and intellectual elites. In the region, civil societies have been coopted, while individuals who have mobilised in opposition to the region's central power structures and ideological establishments have been suppressed. Members of these civil societies are rhetorically tarnished by incumbent regimes as political 
or cultural traitors. Such structures of power remain a threat to human rights. Thus, while the region has remained superficially stable, rights violations have been a source of fundamental opposition to the domestic situation, making the region's political status quo a flashpoint for violence and instability. ${ }^{48}$

Repressive norms are so longstanding that many reject the possibility of the implementation of human rights in the Muslim world, seeing the political culture of the region as irremediably dictatorial. This is not entirely unfounded, since there is a combination of tyrannical structures and ideological nihilism at the heart of the region's current political formations. According to Sharabi, whether secular, monarchical or republican, all forms of rule in the Middle East are akin in their patrimonial foundations and oppressive results. ${ }^{49}$ This raises the crucial question of alternatives and how they might be given political space that would advance the political and economic rights of individuals and direct the region's energies towards genuine economic and political development. ${ }^{50}$

From secular to human rights-based critiques, the Arab world's political ideas have always been understood vis-à-vis dialogue with global currents. However, the region is not a parochial backwater that merely takes note of normative shifts that occur in a transnational context, conceptualising the Arab world as open to change - given the political space - in response to the evolving normative models of change. It is this political space that is essential with regards to guaranteeing individual and group agency, as well as protection of rights in terms of political and economic participation, which "allow peoples to be the subject defining their political structures, rather than the object of structures imposed upon them from above." ${ }^{51}$ In this sense, human rights provide a structure through which alternatives can evolve from within society and out of the global exchange of ideas.

\section{Human Rights Conventions in the Muslim World: Ratification and Reservations}

Given the view that human rights are intrinsically antithetical to Islam, it is noteworthy that the formal discourse on Islam has always promoted compatibility between the two. Nevertheless, while Islam does not deny the universal value of human rights, it does not agree with the universal human rights concept as based on Western imperialist connotations. Referring to the preamble of its charter of 1972, the Organisation of the Islamic Conference (OIC) declared that fundamental human rights are compatible with Islamic values, including the aim of protecting the individual from the state. Thus, for any Muslim state, the reciprocity of the rights of the individual and the duties of the state should be a core area of 
concern..$^{52}$ In the declaration, the recognition of rights was a major development, since individual rights were actually discussed in canonical authoritative corpora in Islam (Qur'an and Sunnah). This was an important innovation at the principle level. ${ }^{53}$ The hybrid character of the Cairo declaration can be understood from the role it grants to the state in guaranteeing the rights of the individual, while also presenting fundamental rights and universal freedoms as an integral part of Islam.

This hybridity is also displayed when Muslim states implement human rights conventions. While some countries have expressed reservations on shariah grounds, others have argued for incorporating shariah into the framework of human rights to give legitimacy to the UDHR. In relation to three major conventions on human rights, namely the International Covenant on Civil and Political Rights (ICCPR), the Convention on the Elimination of All Forms of Discrimination Against Women (CEDAW), and the Convention against Torture (CAT), Muslim countries have ratified all three while maintaining the shariah as an important source of legitimisation. However, references to international human rights in the constitutions of various Muslim countries differ. For example, although Saudi Arabia has no formal constitution, the kingdom refers to human rights under its Basic Law of Governance. Some countries, such as Yemen, refer explicitly to the UDHR or the Charter of the United Nations. ${ }^{54}$

Concerns over gender equality, criminal law and freedom of religion as espoused by the UN conventions continue to pose a challenge from the Islamic point of view. They must be rigorously discussed before they can receive Islam's seal of approval. In regard to freedom of religion, inter-religion dynamics might not pose much of a problem. Classical Islamic scholarship, for instance, accorded special provisions to the "People of the Book," (Jews and Christians), while many modern Muslim constitutions have adopted preferential treatment for nonAbrahamic religions, too (such as Hinduism in Indonesia and Zoroastrianism in Iran). But, problems arise concerning intra-Muslim religious communities, such the Baha'is in Iran, the Alawites in Turkey or the Ahmadis in Pakistan. This complication is derived from the formal status of Islam as part of the state. The Cairo Declaration reads, "Islam is certainly seen as the ultimate revelation" and is formally accorded special treatment "on many fronts (for example, in the marriage and inheritance laws, religious education, access to high state functions). ${ }^{.55}$ Due to the formal position of Islam in the state, intra-Muslim minorities whose beliefs are not acknowledged by the state can become victims of discrimination. This implies that the definition of apostasy can be drawn very broadly. However, according to Mayer, at least on paper there is Muslim acceptance of important human rights conventions, with many Muslim countries making concrete and constructive progress in their implementation over the last decade. ${ }^{56}$ Shifting 
political landscapes in the Muslim world have made it more feasible to reconcile Islam with human rights, and to even regard Islam as a source of human rights. Without creating polarised positions on national and international discussions, this serves as a very important reference point for the development of a Muslim constitutional state guaranteeing equal rights to all peoples, regardless of their religious affiliation. ${ }^{57}$

Focusing on the ICCPR convention, Baderin argues that the primary areas of conflict between human rights and Islam concern the scope of gender equality, freedom of religion, freedom of expression and the death penalty. ${ }^{58}$ However, even in these cases, differences can be minimised due to the breadth of interpretations within the Islamic schools of law. In this regard, Islamic jurists should be given the right to choose appropriate rulings in order to make shariah more flexible and humane, thus enabling it to serve as a platform for the realisation of human rights in Muslim countries.

\section{Conclusion}

Contemporary debates within the Muslim world regarding state formation, globalisation, human rights and nationalist particularisms, are divided into two opposing camps. One side denounces Islam for historically legitimising despotic rule, whereas the other finds that the liberal tendency within Islam is suppressed by modern secular authorities. A critical view of cultural heritage and the identity constructions based on it, as well as the influence of the more powerful cultural "Other," reveals the first interpretation to be an attempt to isolate religion from the secular public sphere. ${ }^{59}$ The advocates of the second approach argue that in order to resist globalisation, individualisation and interdependence, there is a need to embrace their opposites, such as universal liberties, alongside increased nationalism and particularism. ${ }^{60}$ Redefining politics, according to this side, must primarily refer to human rights reform.

Secularists view local cultures as outdated concepts to be replaced by innovative ideas and universal norms, whereas Muslim intellectuals incline towards preserving authentic identity in defence of local culture. Some moderates, however, emphasise the relevance of local cultures in accepting positive global changes, including universally accepted human rights standards. This approach allows human rights values to be incorporated within a religious framework, and thus further facilitate the universalisation of human rights norms. The above process also takes us further away from a view that has bedevilled human rights thinking and practice for a long time: that "the West" is to be identified with liberalism and human rights while "other" cultures are seen as opposing them. 
In this context, the universalisation of human rights principles, which many see as part of a process of globalisation, becomes an important point pertaining to the political transformation of the Muslim world. Given that globalisation does not undermine the authority of a state, it remains for the state to bridge the gap between its domestic standards and universal norms. From the 1970s to the 1990s, in countries such as Egypt and Tunisia, this process created extreme reactions, with Islamists responding to the situation by adopting human rights principles. The status quo indicated that, since this was a reaction to global norms, as well as the states which represented those norms, globalisation and the universalisation of human rights could be reversed. ${ }^{61}$ However, the present situation in the Muslim world is no less favourable than in developing countries. The various indices of human development measure the impact of globalisation on human rights discourse by looking at how human rights have advanced in the face of the grim realities that characterise much of the Muslim world. ${ }^{62}$ Given the trend of religious moderation and political secularism in most Middle Eastern states, important developments have been made, although not to the point of full acceptance of human rights norms. Rights and freedoms are still filtered through an ideological lens that often compels states to undermine human rights principles. However, this does not exclude further rapprochement, and signs of a new transformation can, in fact, be observed in a normative model of human rights that successfully reduces the strain between shariah and international law.

\section{Policy Recommendations:}

- Given that the era of globalisation has energised the moral force of human rights, Muslim nations must focus on developing the most fundamental and basic of those rights - a "minimal morality" - on which a large number of societies can agree.

- While embracing the challenges and opportunities of globalisation, Muslim nations must ward off hegemonic Western ideologies and institutions that have disruptive effects on Muslim societies.

- The process of transformation may require a paradigm shift in contemporary Islamic thinking regarding the relationship between human rights and Islam, a shift that will result in balance and control without necessarily sacrificing Muslim values and ethical perspectives.

- To overcome West-centric biases, the raison d'etre of human rights discourse should be grounded in an intercivilisational perspective. This approach represents a significant scaling back of the imperial aspirations sometimes attributed to the Western project of human rights. 
- Further investigations must explore the relevance of human rights by studying the politically and economically repressive realities that characterise the Muslim world.

\section{Notes}

* Asif Mohiuddin, Senior Research Fellow, SH Institute of Islamic Studies, University of Kashmir, Srinagar, India. He can be contacted at asif. mohiuddin09@gmail.com.

1. Arjun Appadurai, Modernity at Large: Cultural Dimensions of Globalisation (Minneapolis: University of Minnesota Press, 1996), 22.

2. Thomas Cushman, 'The Globalization of Human Rights,' in The Routledge International Handbook of Globalization Studies, ed. Bryan S Turner (London: Routledge, 2010), 597.

3. Olivier Roy, Globalised Islam: The Search for a New Ummah (New Delhi: Rupa and Co., 2004), 32.

4. Shahram Akbarzadeh and Benjamin MacQueen, 'Framing the debate on Islam and human rights,' in Islam and Human Rights in Practice: Perspectives across the Ummah, ed. Shahram Akbarzadeh and Benjamin Macqueen (London: Routledge, 2008), 1-11.

5. Johannes Morsink, The Universal Declaration of Human Rights: Origins, Drafting and Intent (Philadelphia: University of Pennsylvania Press. 1999), 1634.

6. Syed Khatab, 'Hakimiyyah and Jahiliyyah in the thought of Sayyid Qutb,' Middle Eastern Studies 38, no.3 (2002): 145-70.

7. Abdullah Saeed, Interpreting the Qur'an: Towards a Contemporary Approach (London: Routledge, 2006), 53.

8. Katerina Dalacoura, Islam, Liberalism and Human Rights: Implications for International Relations (London: I.B. Tauris, 2006), 128.

9. Jack Donnely, International Human Rights, $3^{\text {rd }}$ ed. (Boulder: Westview Press, 2007), 210.

10. John R. Scholte, Globalization: A Critical Introduction (New York: Palgrave Macmillan, 2005), xvii.

11. Derrick M. Nault, 'Introduction,' in Globalization and Human Rights in the Developing World, ed. Derrick M. Nault and Shawn L. Englan (London: Palgrave Macmillan, 2011), 3.

12. Karen Engle, 'From Skepticism to Embrace: Human Rights and the American Anthropological Association,' Human Rights Quarterly 23, no.3,(2001): 536-59.

13. Mary Ann Glendon, A World Made New: Eleanor Roosevelt and the Universal Declaration of Human Rights (New York: Random House, 2001), 35-51.

14. Jane K. Cowan, M.-B. Dembour and Richard A. Wilson, 'Introduction,' in Culture and Rights: Anthropological Perspectives, ed. Jane K. Cowan, MarieBénédicte Dembour and Richard A. Wilson (Cambridge: Cambridge University Press. 2001), 1-30. 
15. M.-B. Dembour, 'Following the Movement of a Pendulum: Between Universalism and Relativism,' in Culture and Rights: Anthropological Perspectives, ed. Jane K. Cowan, Marie-Bénédicte Dembour and Richard A. Wilson (Cambridge and New York: Cambridge University Press. 2001), 56-79.

16. Clifford Bob, The Marketing of Rebellion: Insurgents, Media, and International Activism (Cambridge: Cambridge University Press), 1-5.

17. Abdur Rahman Sheha, Human Rights in Islam and Common Misconceptions (Alexandria: Abu Salman Deya Ud Deen, 2010).

18. Muhammad Hashim Kamali, An Introduction to Shari'ah (Kuala Lumpur: Ilmiah Publishers, 2006), 130-1.

19. Muhammad Hashim Kamali. Freedom, Equality and Justice in Islam (Cambridge: Islamic Texts Society, 1999), 196-7.

20. Imran A. K. Neyazee, 'Islamic Law and Human Rights,' Islamabad Law Review 1, no.1 (2003): 34.

21. Asif Mohiuddin, An Islamic Approach to Human Development: Democracy and Human Rights in the Light of Maqāsid al-Sharī'ah. Available at: www. iais.org.my/e/attach/2015/maqasid2015/pdf/s3s1_paper.pdf. (Accessed on: 27/12/2018).

22. Muhtari A. Kano and Atallah Fitzgibbon, Human Development in Islam (Birmingham: Islamic Relief Worldwide, 2014), 7.

23. Najib Ghadbian, Democratization and the Islamist Challenge in the Arab World (Boulder: Westview Press, 1997), 74.

24. Umar Chapra, The Islamic Vision of Development in the Light of Maqasid alShari 'ah (London: International Institute of Islamic Thought, 2008), 11.

25. Jasser Auda, 'Islam,' in Encyclopedia of the Developing World, Vol 1, ed. Leonard Thomas (London: Routledge, 2006), 875-9.

26. Jasser Auda, Maqasid al-Shari 'ah: A Beginner's Guide (London: International Institute of Islamic Thought, 2008), 25.

27. Asbjorn Eide, 'National Sovereignty and International Efforts to Realize Human Rights,' in Human Rights in Perspective: A Global Assessment, ed. Asbjorn Eide and Brent Hagvet (Oxford: Blackwell, 1992), 3-30.

28. Rudolfo Stavenhagen, 'Universal Human Rights and the Cultures of Indigenous Peoples and Other Ethnic Groups: The Critical Frontier of the 1990s,' in Human Rights in Perspective: A Global Assessment, ed. Asbjorn Eide and Brent Hagvet (Oxford: Blackwell, 1992), 135-151.

29. Brian Beeley, 'Islam as a Global Political Force,' in Global Politics: Globalization and the Nation State, ed. Anthony McGrew and Paul Lewis (London: Polity Press, 1992), 293-311.

30. Roy Andersen, Robert Seibert and Jon Wagner, Politics of Change in the Middle East: Sources of Conflict and Accomodation, $5^{\text {th }}$ ed. (Upper Saddle River, NJ: Prentice Hall, 1998), 145.

31. Mir Husain, Global Islamic Politics (New York: Harper Collins 1995), 156.

32. 24 Human Rights Documents (New York: Centre for Study of Human Rights, Columbia University, 1992), 8.

33. Mahmood Monshipuri, 'Islam and Human Rights in the Age of Globalization,' in Islam Encountering Globalization, ed. Ali Mohammadi (London: Routledge, 2002), 102. 
34. Asma Afsaruddin, Striving in the Path of God: Jihad and Martyrdom in Islamic Thought (Oxford: Oxford University Press, 2013), 242.

35. Kamali, Freedom, Equality and Justice, 203-34.

36. Tariq Ramadan on Apostasy. Available at: http://www. https://berkleycenter. georgetown.edu/quotes/tariq-ramadan-on-apostasy. (Accessed 5 April 2018).

37. Jonathan Brown, Misquoting Muhammad: The Challenges and Choices of Interpreting the Prophet's Legacy (Oxford: Oneword Publications, 2014), 1869. Quran 2:256 and 18:29.

38. Khaled Abou El-Fadl, The Great Theft: Wrestling Islam from the Extremists (New York: HarperCollins, 2007), 158-9.

39. Dean Paterson, Delores Wunder and Harlan Mueller Harlan, Social Problems: Globalization in the Twenty-First Century (Upper Saddle River, NJ: PrenticeHall, 1999), 38-9.

40. Akbar Ahmad and Hastings Donnan, 'Islam in the Age of Postmodernity,' in Islam, Globalization and Postmodernity, ed. Akbar Ahmad and Hastings Donnan (New York: Routledge, 1997), 17.

41. Meyer, Human Rights, 216.

42. Heiner Beilefeldt, 'Muslim Voices in the Human Rights Debate,' in Islam and Globalization, Vol 4, ed. Shahram Akbarzedeh (London: Routledge, 2006), 226254.

43. Fazlur Rahman, Islam (Chicago: Chicago University Press, 1979), 27.

44. Abdullahi An-Na'im, Toward an Islamic Reformation: Civil Liberties, Human Rights, and International Law (New York: Syracuse University Press, 1990), 75.

45. Riffat Hassan, 'On Human Rights and the Qur'anic Perspective,' in Human Rights in Religious Traditions, ed. Arlene Swidler (New York: Pilgrim Press, 1982), 51-65.

46. Available at: https://escholarship.org/uc/item/7bv4b2w1(accessed 5 April 2018).

47. Anthony Chase, 'The State and Human Rights: Governance and Sustainable Human Development in Yemen,' International Journal of Politics, Culture, and Society 17, no.2 (2003): 213-236.

48. Since the 2011 popular uprisings, human rights in the Middle East and North Africa have suffered at the hands of authoritarian regimes willing to use any means necessary to stifle the democratic aspirations of their citizens. Even in stable countries such as Egypt and Bahrain, human rights violations have spiraled. Egyptians since the 2013 coup have endured rights violations unthinkable, even during the worst days of former president Hosni Mubarak. Likewise, in Bahrain, "once something of a beacon of pluralism in the Gulf, opposition political leaders are imprisoned and tortured, while human rights activists are treated as enemies of the state." At the heart of the global retreat of human rights is the Syrian tragedy. The causal chain is discernable. The entrenched regime resorted to unpunished mass murder, which led to the rise of extremism within the country. The combination resulted in the flight of millions of Syrians to Europe in the summer of 2015, which culminated in "a characteristic entrenchment of anxious populations worried about the impact of poor and destitute immigrants on already diminishing entitlements." Thus, it reinforced "intolerant populism across the Western world, and led to the arrival to power of [such] leaders in Eastern Europe and in the United States." The defense of human rights is now 
mostly left to international civil societies, with human rights and humanitarian organisations in the lead. Available at: http://carnegie-mec.org/diwan/75607. (Accessed on: 21/06/2018).

49. Hisham Sharabi, Neopatriarchy: A Theory of Distorted Change in Arab Society (Oxford: Oxford University Press, 1988), 66-70.

50. Muhammad Hafez, Why Muslims Rebel: Repression and Resistance in the Islamic World (Boulder: Lynne Rienner Publishers, 2003), 19-20.

51. Chase, 'The State and Human Rights,' 11.

52. Meyer, Human Rights, 14.

53. Available at: http:// http://edoc.vifapol.de/opus/volltexte/2008/487/pdf/ AP_13_1999.pdf. (Accessed on: 05/04/2018).

54. Saì Mahmoudi, 'International Human Rights Law as a Framework for Emerging Constitutions in Arab Countries,' in Constitutionalism, Human Rights, and Islam after the Arab Spring, ed. Rainer Grote and Tilman Roder (Oxford: Oxford University Press, 2016), 537.

55. Donk et.al. Dynamism in Islamic Activism: Reference Points for Democratization and Human Rights (Amsterdam: Amsterdam University Press, 2006), 138.

56. Mayer, Human Rights, 10

57. Shireen Ebadi, Human Rights, Women and Islam, ISIM-Lecture, The Hague, 16 April 2004.

58. Mashoud Baderin, International Human Rights and Islamic Law (New York: Oxford University Press, 2003), 20.

59. Amr Hamzawy, 'Globalization and Human Rights: On a Current Debate among Arab Intellectuals,' in Human Rights in the Arab World, ed. Anthony Chase (Pennsylvania: University of Pennsylvania Press, 2008), 62.

60. James Spickard, 'Human Rights, Religious Conflict, and Globalisation,' International Journal on Multicultural Societies 1, no.1 (1999): 16.

61. Fred Halliday, Islam and the Myth of Confrontation: Religion and Politics in the Middle East (London: I. B. Tauris, 1999), 134.

62. Abdulaziz Sachdena, Islam and the Challenge of Human Rights (Oxford: Oxford University Press, 2009), 145. 